\title{
CÁRCERE: UM SISTEMA FALIDO DE RESSOCIALIZAÇÃO
}

\section{Laís Faria Giudice Mota ${ }^{1}$ \\ Ilka Ramos ${ }^{2}$ \\ Mauricio Martins Alves ${ }^{3}$}

Resumo: A pena privativa de liberdade foi importante meio de humanização das penas impostas aos condenados, substituindo os grandes espetáculos de punição existentes antes do séc. XIX. Não obstante, após tornar-se a principal resposta penalógica ao fato criminoso, a eficácia da pena privativa de liberdade precisa ser questionada. O presente artigo tem por escopo o estudo da falência da pena privativa de liberdade, suas causas e consequências. Através da pesquisa foi possível organizar e analisar os principais fatores que tornam essa modalidade de pena inadequada para o combate à criminalidade. Concluiu-se que a prisão, verdadeira instituição total, com condições materiais e humanas degradantes, produz uma série de efeitos deletérios, não sendo apta a dar conta da finalidade da pena representada pela ressocialização. Palavras-chave: Cárcere; Pena; Falência; Ressocialização; Apenado.

\footnotetext{
1 Direito/UNIVAP, Brasil. E-mail: laisgiudice@hotmail.com.

2 Direito/UNIVAP, Brasil. E-mail: ilka@univap.br.

3 Direito/UNIVAP, Brasil. E-mail: mmalves@univap.br.
} 